JELENA BILJETINA ${ }^{1}$

Univerzitet u Novom Sadu

Pedagoški fakultet u Somboru

\section{STRUČNI ČLANAK}

UDK: $\quad 81 ' 255.4: 821.111-31$ McEwan I.

BIBLID: 0353-7129, 26(2021)2, p.255-268

\title{
ON SOME ASPECTS OF TRANSLATION: ON CHESIL BEACH BY IAN MCEWAN AND ITS TRANSLATION INTO SERBIAN
}

\begin{abstract}
Summary: The goal of this paper is to analyse some segments of Ian McEwan's novel On Chesil Beach and their translation into Serbian. The main aim is to analyse to what extent the translator managed to transfer the meaning of the original text into Serbian. The translation is analysed on the semantic and pragmatic levels. The method used to compare and contrast the source text language and the language of the Serbian text is contrastive analysis. The obtained results of the analysis show that the message of the original text was in most cases successfully transferred into Serbian. Keywords: translation, contrastive analysis, semantic level, pragmatic level
\end{abstract}

\section{INTRODUCTION}

The main goal of this paper is to analyse some aspects of the translation of Ian McEwan's novel On Chesil Beach. The analysis will be done on the semantic and pragmatic levels, as these aspects, the first linguistic, and the other extralinguistic, along with the grammatical aspect, make the whole of a communicative situation (Prćić, 2008). According to Newmark (1988), translation is related to both referential and pragmatic levels. The main hypothesis in the paper is that the meaning of the English text has been attained in the Serbian translation at the semantic and pragmatic levels.

The analysis is done on the grounds of the theoretical and methodological postulates presented in Section 2 (Theoretical Background) and Section 3 (Corpus and Methodology) of this paper, while the analyzed segments of the text and the discussion

$\overline{1 \text { jelena.biljetina@gmail.com }}$ 
are presented in Section 4 (Analysis). The final chapter (Conclusions) summarizes the results of the analysis.

\section{THEORETICAL BACKGROUND}

Translation refers to the specific relation between languages which has been defined from various perspectives. Ivir (1978) defines the act of translation as the transference of a message expressed in one language into a message that has the same meaning in another language. Nida and Taber (1982) focus on the communicative function of translation: the task of translation is not merely for the average recipient of the message to understand it, but to be certain that the recipient is very unlikely to misunderstand it. Newmark (1988) defines the translation process as an activity pulled by several opposing forces, referring to the interlinguistic and the extralinguistic factors, to the semantic and the pragmatic in translation. Eco (2008) defines translation as the interpretation of two texts in two different languages where the main task is to successfully communicate the message.

Catford (1978) points out that translation can be set up between any languages, whether they are separated by space, time, social or other relations. He defines translation as 'the replacement of textual material in one language (SL) by equivalent textual material in another language (TL)' (Catford, 1978: 20). The language that is being translated into is the Target Language (TL), while the language that is being translated from is the Source Language (SL). In this paper, the SL is English, while the TL is Serbian. The central task of the translation process is to find translation equivalents in the TL, or to find a form in the TL that would be equivalent to the given form in the SL (Catford, 1978).

The translation of literary texts allows more freedom for the translator in order to achieve the same artistic effect (Ivir, 1978). ${ }^{2}$ A translator needs to explore the text as a whole and to set it into wider social, ethnical, national and time frames (Stojnić, 1980). Although the principles of translation must be followed, the translators are entitled to change a surface story in order to preserve its deep sense (Eco, 2008). There are, though, instances where the translation does not interpret the original effect, but the translation cannot simply reproduce, or be, the original (Newmark, 1988). Therefore, the role of the translator is to act as a mediator and to decode the message coded in a SL into the code of the TL.

\section{CoRpus and Methodology}

The corpus for this paper consists of the chosen segments of the English novel On Chesil Beach written by Ian McEwan, and their translation into Serbian by Arijana

2 Ivir, however, does not advocate the division into literary and non-literary texts. His view is that a translator's approach to translation has to remain the same, as in both cases the crucial notion is to express the message of the SL into an equivalent message in the TL (Ivir, 1987). 
Božović, Čezil Bič. Both the original text and its translation will be decomposed into units of various length (lexemes, syntagms, clauses, sentences). Considering the main aim and hypothesis in this paper, which are both related to the specific aspects of the translation analysis, the main method employed will be the comparative method, based on the semantic and pragmatic analysis of the content of the original and the translated texts.

A comparative method is a segment of the process of contrastive analysis which aims at finding similar, contrasting and different structures in (at least) two languages (Đorđević, 1987). Although purely linguistic discipline, its results are widely used in the translation process since translation aims at establishing similar structures in the language that a certain language segment is translated into. Contrastive analysis, as such, is oriented towards those elements of the two languages that stand in the mutual relation of translation (Ivir, 1987). However, this relation is not a unilateral one, as there is always a certain feedback between contrastive analysis and translation (Đorđević, 1987).

In this paper, the elements from the source language text will be grouped into two categories (semantic and pragmatic) and they will represent a selective but representative corpus that will be used for the detailed comparison of the translation with the original (Newmark, 1988). The analysis of the selected corpus will be presented in the following chapter.

\section{ANALYSIS}

On Chesil Beach is the novel set in 1962. The central characters are Edward and Florence, the newlyweds, who have come to a hotel on Chesil Beach just after they got married in Oxford. They both worry about the consummation of their marriage, though in different ways: Florence is terrified by the prospect of sexual intercourse, while Edward has more conventional, typical men's worries about the intercourse. As it is 1962 , it is not considered appropriate to talk about sex and that is why the inner turmoil of these two young people leads to the catastrophe. The central events in the novel take place during one night, Edward's and Florence's weeding night, but the author reveals more about them through several flashbacks which unveil the differences between Edward and Florence. These are mainly class differences - their different upbringings and the milieu they grew up in are completely different, but it is not the only reason for their break-up. The novel deals mainly with the atmosphere in England and criticizes the conservative society for not being able to talk openly about problems that were (and still are) happening to people. They are constricted by the times in which they live and this is what eventually leads to the clash and explains why the catastrophe has happened. The tension that reveals itself from the first page logically leads to the disaster that happens between the two young people in love.

The style that Ian McEwan uses may seem as literary simple at first glance, but the simple sentences and the properly chosen words with the slightly humorous tone 
provide the reader with the main characters' most inner feelings. The novel is written in third person narration. The author is neutral, but compassionate towards the couple as he puts no blame on them. It is written in the past tense and is mainly a narrative, with several flashbacks that reach further into the past and to the pre-married lives of Edward and Flo. The author also reveals the two main characters' thoughts and ideas, but indirectly, even Edward and Florence remain unaware of how their own past experiences influence their behaviour during their wedding night. McEwan succeeded in remaining hidden throughout the novel, yet somehow present, as it is the narrator who reveals the characters' past. The following analysis will try to examine to what extent the translation follows the language and the tone of the novel.

\section{The semantic analysis}

The semantic analysis is aimed towards the analysis of vocabulary, or, more precisely, of the meaning of lexemes. However, the translation of lexis (and the analysis of the translation of lexis) is restricted by the capacity of lexemes to have many different meanings (Nida \& Taber, 1982). This capacity becomes even more complex when the two languages are contrasted, as in translation, where the translator is faced with the choice among several different meanings that a certain word has. Analyzing the semantic content solely, therefore, is not enough: contextual specifications resolve the ambivalence of terms (Nida \&Taber, 1982) and the surrounding lexemes add to the meaning of specific lexemes. In this paper, the semantic analysis will focus on the lexical units, particularly collocations and phrasal verbs, which represent the part of the linguistic context and are language specific. These units were contrasted in order to analyze how close the meaning and the message of the original text have been preserved in translation.

The analysis will begin with several collocations that were successfully translated. The first one is $(1 \mathrm{a}, 1 \mathrm{~b})$, where formal was not translated by the corresponding lexeme in Serbian, formalni or zvanični, but by the adjective svečani. The translator opted for a better solution, because the formal meal refers to the meal that was served to Florence and Edward when they got to the hotel. It was their first meal as the husband and wife, and the adjectives formalni or zvanični are too strong to use in this context, as their meaning is official and is more appropriate for a different context.

$$
\begin{aligned}
& \text { 1a ...the formal meal began... } \mathrm{p}^{3} \\
& 1 \mathrm{~b} \text {...svečani obed je započeo... } \mathrm{p} 10
\end{aligned}
$$

In $(2 a, 2 b)$ the collocation is the combination of the verb and the adverb that describes the manner in which they do the action. There is a corresponding phrase in Serbian, videti jasno, but the translator opted for transposition and the change of the part of speech. The Serbian translation is a noun phrase, jasan pogled. The translator

3 The number following each example refers to the page number of the original and the translated book. 
probably decided to make changes in the word order and in the syntax of the sentence because in that case the focus is also on these new heights, just as it is in English.

\section{2a From these new heights they could see clearly... p7}

$2 \mathrm{~b}$ Imali su jasan pogled s tih novih visina... p11

$(3 \mathrm{a}, 3 \mathrm{~b})$ is similar to the above example, as here, too, the translator used transposition: the noun memory is transposed into a verb phrase in Serbian. Such transposition, although not necessary (as it is both grammatically and lexically possible to express the same phrase in Serbian as nemati sećanje) is justified because such solution sounds more natural in Serbian (Hlebec, 2009).

3a Florence had no memory of being on the team... p46

3b Florens se nije sećala da je bila u timu...p33

The adjective tone-deaf in (4a) was translated into Serbian by a noun, which is another example of the change in the part of speech. This is the successful translation because the meaning of the source adjective was fully preserved: the noun, antisluhista, denotes a person who is not very good at recognizing different tunes, which also refers to the meaning of tone-deaf.

4a She was so tone-deaf... p61

$4 \mathrm{~b}$ Ona je bila takav antisluhista... p42

In $(5 \mathrm{a}, 5 \mathrm{~b})$ the collocation, a noun phrase, was translated into Serbian by a verb phrase, which is more appropriate than the corresponding noun phrase in Serbian (slučajno otkriće) because what follows the collocation does not sound natural when translated into Serbian. The sentence is in the past tense, and the translator successfully transposed the noun discovery into the corresponding verb in Serbian (otkriti), while the adjective incidental was accordingly changed into the adverb which has the same meaning as the English adjective.

5a An incidental discovery was that even legendary success brought little happiness...p16

$5 \mathrm{~b}$ Uzgred je otkrio da čak ni legendaran uspeh ne donosi mnogo sreće...p16

Another example of a successful translation is $(6 a, 6 b)$, where the English collocation was translated by a fully corresponding collocation in Serbian. This translation also shows that the indefinite article was translated into Serbian as nekim.

6a Whenever she confronted an intimate problem...p12

$6 \mathrm{~b}$ Suočena s nekim intimnim problemom... p14 
The collocation in (7a) was translated by an antonymic phrase (7b). In Serbian it is not natural to use the corresponding phrase (biti $u$ krivu), although it is grammatically allowed. The translator opted for the combination of the corresponding verb in its negative form and the opposite adjective. Such translation is justified, as it keeps the balance between the original and the translated phrase (Hlebec, 2009).

7a ... and who could say for sure that she was wrong? p39

$7 \mathrm{~b}$... a ko bi se mogao zakleti da nije u pravu? p29

There are several examples of successfully translated collocations where the translator also used antonymy, mostly negation. In (8b) the verb with the opposite meaning was negated. Here, the translation was appropriate because holding down refers to the summoning bell that the guests need to press in case they need room service. The verb in Serbian pritisnuti itself implies that something is held down, therefore there is no need to repeat its meaning by the verb držati (which is the formal correspondent of hold).

8a ...it must be pressed hard and held down...p21

$8 \mathrm{~b}$....neka samo pritisnu jako i ne puštaju...p19

(9b) represents the successful translation of an idiomatic phrase which was translated by an antonymic idiomatic phrase which partly transfers the meaning of the original. The translator chose the idiom which is not a formal correspondent of the English idiom, but which has a similar meaning: tall tales refer to stories that are exaggerated, while the Serbian idiom refers to the stories that are hard to believe in. Although the meanings do not overlap, priče za malu decu is an adequate solution because it has the same effect on a Serbian reader as tall tales have on an English reader.

9a ... another of these tall tales about America... p48

$9 \mathrm{~b}$...još jedna američka priča za malu decu...p35

Another successful translation is (10b), where the translator used antonymy: the reason is partially syntactic in nature, because the translator, contrary to the original, used the verb which represents an antonym to ask and which is used in its active form.

10a ...but she resented being asked at each breakfast whether she had. p61

$10 \mathrm{~b}$... ali bilo joj je mrsko da za doručkom odgovara na pitanje da li ga je namestila. $\mathrm{p} 42$

$(11 \mathrm{a}, 1 \mathrm{~b})$ is an example of the translation with a modified meaning. Here, the translator changed the part of speech (the verb prepare into a noun priprema) and 
slightly modified the meaning of the original phrase with the adjective slab (weak or poor), instead of merely translating the negated verb phrase. This seems to be a good solution, because the original message was preserved. However, there are two phrases in the translation of this sentence into Serbian which do not seem to be a good solution: pita sa čipsom and oberžin. Pita sa čipsom does not refer to the concept denoted in the English sentence and was, therefore, wrongly translated. Pie-and-chips regime is related to the poor quality of food that Edward was eating during his student days and the chips in this syntagm should be translated as pomfrit or prženi krompir. Another inadequate translation is oberžin - it is not clear why aubergine was translated in this way, particularly because it has a formal correspondent in Serbian which is widely used in everyday language (patlidžan).

11a ...the pie-and-chips regime of his student days could not have prepared him for the strange vegetable- aubergine... p145

$11 \mathrm{~b}$...pita sa čipsom iz studentskih dana bili su slaba priprema za neobično povrće -oberžin... p90

The fixed expression lunchtime meeting in (12a) was also successfully translated as $u$ vreme pauze za ručak, as there is no adjective in Serbian that could be derived from the noun ručak (lunch). The translator, therefore, opted for a descriptive translation. The verb hesitate has its correspondent in Serbian. Oklevati matches it both in its form and meaning. The translator used the idiomatic phrase našao se u nedoumici because the following sentence states that Edward was in two minds and that he stopped for a moment to think whether to enter the meeting room or not.

\section{2a ...he saw a handwritten sign advertising a lunchtime meeting of the local CND and hesitated... p58 \\ $12 \mathrm{~b}$...primetio je rukom ispisan oglas o sastanku CND-a u vreme pauze za ručak i odjednom se našao u nedoumici... p40}

In (13b) the translator used the verb odlaziti (go) instead of piti (drink) because this verb, when used in its imperfective form, implies going somewhere at certain intervals and is more appropriate to use in this context. It refers not only to drinking beer but to belonging to the group of mates.

13a He worked all day, played football at weekends and drank beer with his mates. 446

13b Radio je počitav dan, a vikendom igrao fudbal i odlazio na pivo $s$ drugarima. p34

Unlike the previous example, where the translator widened the meaning of the verb, in (14b) the noun phrase was narrowed in its meaning and the translator 
specified the meaning of the couple. This is justified since the equivalence in meaning has been attained, and the lexeme mladenci (bride and groom) implies the meaning of the couple.

14a The couple were briefly alone...p15

14b Mladenci su nakratko ostali sami... p15

The idiomatic phrase in $(15 \mathrm{a}, 15 \mathrm{~b})$ was successfully translated into Serbian by a corresponding phrase. The meanings of the lexemes in the two phrases do not match, but the meanings of the whole phrases do and they also bear the same connotation.

$15 \mathrm{a}$...Florence...was an old hand. p3

$15 \mathrm{~b} . .$. dok je Florens... u takvim stvarima već bila prekaljena. $\mathrm{p} 9$

$(16 \mathrm{a}, 16 \mathrm{~b})$ is another example of an adequately translated idiom. Here the translator also used a fixed phrase in Serbian: the lexemes in the translation match in their meanings with the lexemes in English.

16a Then at last they were back on course. p27

$16 \mathrm{~b}$ Onda su se konačno vratili na pravi kurs. p22

Phrasal verbs represent another group that may be challenging for translating, mostly when their meaning is not transparent. The (17a, 17b) example was translated as izlaziti according to the meaning of the verb and the particle in it.

17a She never came out to speak to him... p54

17b Nikad nije izlazila da razgovara sa njim... p38

The situation is similar in $(18 \mathrm{a}, 18 \mathrm{~b})$ : here, too, the combination of the verb and the particle is transparent and the translator has translated them appropriately as zavaliti. Zavaliti in Serbian is an informal verb, but it suits the context because Edward is relaxed and satisfied.

18a Edward smiled as he sat back with his wine... p14

$18 \mathrm{~b}$ Edvard se sa osmehom ponovo zavalio u stolicu... p15

In (19a, 19b) the translator rightly chose to translate speak up as izjasniti (state one's opinion clearly) since this meaning does not refer to the context. It is one of its secondary meanings (to give an opinion) that is appropriate in this context.

19a She knew that she should have spoken up long ago... p11

$19 \mathrm{~b}$ Znala je da se već odavno morala izjasniti... p12 
(20a, 20b) is the sentence with two phrasal verbs, nip forward and clear away. The meaning of clear away is transparent, and was translated by the corresponding verb raspremiti. Nip forward has several meanings, while in this context its meaning refers to coming quickly; therefore the translator used the appropriate verb prici $i$, modified with the adverb of manner hitro (quickly).

20a The boy who had spoken had nipped forward to clear away. p14

20b Onaj mladić što mu je malo pre odgovorio hitro je prišao da raspremi sto. $\mathrm{p} 15$

In $(21 \mathrm{a}, 21 \mathrm{~b})$ the meaning of the phrasal verb is not transparent, particularly because the verb is highly polysemous. The translator chose the verb with the adequate meaning, because the context reveals that Edward was startled by the various new kinds of food that he tasted for the first time at the Pontings, especially on that particular occasion when Florence's mother served undercooked peas.

21a He was surprised, even a little put out... p145

$21 \mathrm{~b}$ Iznenadio se, pa čak i malo uvredio... p90

(22a, 22b) has two phrasal verbs, fall out and make up, neither transparent in their meaning, but both successfully translated as sporečkati and izmiriti, respectfully.

22a She knew very well that people fell out, even stormily, and then made up. p63

22b Vrlo je dobro znala da ljudi umeju da se sporečkaju, katkad i burno, a potom izmire. $\mathrm{p} 43$

Focusing on the meaning of the lexemes, the semantic analysis revealed that the translation of the lexemes was oriented towards the context, as the translator tried to keep the original message of the source text and in most cases had to use equivalent forms.

\section{The pragmatic analysis}

The following section will analyse the translation from a pragmatic standpoint, regarding not only linguistic, but extralinguistic context, too, and will try to reveal the way the translator regarded the words which are culture specific. Pragmatics, focusing not only on the linguistic but on the extralinguistic aspects as well, cannot be distinguished from semantics and syntax (Eco, 1994).

The two examples (23a, 23b) and (24a, 24b) represent the successful translation of the culturally related phrase French window. According to the Oxford Dictionaries Online, a French window is 'each of a pair of glazed doors in an outside wall, serving 
as a window and door, typically opening onto a garden or balcony'. There is no lexical unit in the Serbian language that refers to this concept, therefore, it depends on the translator and their lexical potential in what way the problem will be solved (Ivir, 1978). In (23b) the translator chose staklena vrata, which is a descriptive phrase. Staklena vrata represents a part of the definition of a French window (back translation would be glass door). However, this is the successful translation when the whole situation is taken into consideration: Edward and Florence are sitting in their room and having dinner by French windows, which are probably related to the view from the dinner table, and the translator, therefore, used the appropriate phrase, as staklena vrata implies that Edward and Florence can also see through them. In (24b) the translator used only vrata, but this is also appropriate to the context because the important message here is that the door was open (it is clear that it is the previously mentioned French windows) and the breeze carried through it a specific scent, which was transferred into Serbian, too.

\section{3a So they were eating in their rooms before partially open}

French windows... p4

23b I tako su sada obedovali u zasebnom salonu naspram

poluotvorenih staklenih vrata... p10

24a ...carried through the parted French windows an enticement... p22

$24 \mathrm{~b}$...unosio je kroz rastvorena vrata nešto primamljivo... p19

There are also cases that are related to the different conceptualization of time in the two languages. In $(25 \mathrm{a}, 25 \mathrm{~b})$ the translator used the syntagm kasno popodne (instead of the formal correspondent rano veče) because this is the way in which that part of the day is referred to in the Serbian language.

25a The couple had driven away... and arrived in the early evening... p4

25b Na medeni mesec su krenuli...i kasno popodne prispeli... p9

Similarly, in (26a, 26b), the translator used the phrase mesecima (for months) because it is the phrase that refers to a long time it takes to do something, and is appropriately used in this context.

26a That single mistake took weeks to repair. p112

26b Mesecima se trudio da ispravi tu jednu grešku. p71

Another example of a culturally related word is found in $(27 \mathrm{a}, 27 \mathrm{~b})$ : here, the translator opted for večernje piće which is a better solution from the formal correspondent noćne kape, because putting on night caps is not typical for Serbian culture. A reader in Serbian certainly understands what noćne kape implies, but it 
seems that the effect on the reader would be better with večernje piće as it is more indicative of the atmosphere that is being described.

27a ...taking the measure of the world with their night caps. p29

$27 \mathrm{~b}$...pretresajući stanje sveta uz večernje piće. p23

The translation was also successful in several cases related to material culture, as the following examples show. In $(28 \mathrm{a}, 28 \mathrm{~b})$ the translator added the lexeme koledž in front of Christ Church although it is not found in the original text. It is, though, required in the translation because a Serbian reader is probably not familiar with what Christ Church is.

28a ....and eat it on Christ Church meadow...p67

$28 \mathrm{~b}$...i pojede je na livadi ispred koledža Krajst Čerč...p45

In $(29 \mathrm{a}, 29 \mathrm{~b})$ the translator also added an explanation because the readers in Serbian need to know why it was noted in the English text that Violet Ponting was a friend of Elizabeth David.

29a ....and Violet, a sometime friend of Elizabeth David...p146

29b ...Vajolet, školska drugarica slavne kuvarice Elizabet Dejvid...p91

There are, though, examples of not successfully translated words which refer to measuring distance. In $(30 \mathrm{a}, 30 \mathrm{~b})$ and $(31 \mathrm{a}, 31 \mathrm{~b})$ a better solution would be if the translator converted yards into meters, as the distance in question would be more appropriate for the readership in Serbian. Na dvadesetak metara od njega and preostalih nekoliko metara would also sound more natural in Serbian than the offered translation.

30a Fifty yards away... p54

30b Na pedeset jardi odnjega...p38

31a ...and walked him the last fewyards to the very end of the garden... 899

$31 \mathrm{~b}$... i poveo ga još onih preostalih nekoliko jardi do kraja bašte... p57

Another unsuccessful example is the translation of the phrase blue stocking, where the translator chose to use literal translation and to translate the phrase word for word as plava čarapa. Blue stocking is culturally related to the English language and history and is used to refer to an intellectual, educated woman, not quite liked by men, but it does not have any connotation in Serbian. A better and a more suitable solution in Serbian would be intelektualka. 
32a ....and her mother... an old-fashioned bluestocking. p12

$32 \mathrm{~b}$... a majka je...bila prava staromodna "plava čarapa". p14

Moreover, the passive phrase were about to be violated in (33a, 33b) was also wrongly translated. The translator was probably misled by the noun violence, which is used to refer to the behavior intended to hurt people, but such reference is too strong in this sentence. What the writer meant was that Florence's happiness was about to be disturbed or broken; therefore a more appropriate translation would be njena pribranost $i$, u suštini, sreća biće ugroženi.

33a ... her composure and essential happiness were about to be violated. $\mathrm{p} 10$ $33 \mathrm{~b}$...njenoj pribranosti $i$, u suštini, sreći, pretilo je nasilje.p13

The pragmatic aspect of the analysis had to be carefully considered by the translator as in some cases additional explanations were needed because of the culturally specific and different concepts. The translator succeeded in making some of the concepts closer to the Serbian audience, although others remained unexplained.

\section{CONCLUSIONS}

The translation analysis in this paper was done by grouping particular problems in the English text into two groups, semantic and pragmatic, which were analyzed according to the selected problems within each group.

The semantic level of the analysis showed that the translation of the lexical units was oriented towards keeping the original message. In many cases, the translator used the corresponding lexical unit, but it was not always possible, due to the specific syntactic and lexical distribution of both languages. Therefore, in many cases the translator used transposition and changed the part of speech in order for the lexemes and phrases to sound natural in Serbian. With the same goal, the translator used antonymy in several cases, mostly with the verbs which were either negated or which were used as the antonyms of the English verbs. Synonymy is another dimension that also requires careful consideration: although some lexemes did not seem problematic to translate, their translation had to be done according to the context they appear in, and the translator successfully translated them by the lexemes with a wider or narrower meaning than the original.

The pragmatic analysis was focused on a wider linguistic context and on the whole communicative situation that the text is based upon. It is a complex analysis as it comprises not only linguistic (grammatical and semantic), but extranlinguistic level, too. The pragmatic analysis of the translation showed that the translator successfully managed to transfer certain culturally specific words and to make them closer to the Serbian readership, and these are mostly related to the translation of those units that have the same conceptualisation in both the languages, but are lexicalized differently. 
When the elements of the source language culture are not recognized as familiar in the target language, the translator used descriptive translation, which enabled the target language reader to understand the author's message and the implications it bears. The translator, however, should have used metric system instead of the Imperial system, because these measures (yards, in particular, were used by the author in the novel) are not used amongst the readership in Serbia.

The analysis of the translation of the novel On Chesil Beach was based on the semantic and pragmatic analysis of the text. It showed that the main aim of the paperto analyse whether the message of the original text was attained in the target language text - was achieved. The meaning, the message and the general atmosphere of the original text were preserved in the translation into Serbian. However, the successful transference of the message was possible only because the translation did not always follow the grammatical, semantic and (to certain extent) pragmatic levels, but in some cases, depending on the context, one level had to be abandoned in order to achieve the closest possible meaning. The translation, therefore, communicates successfully with the Serbian language readers.

\section{REFERENCES}

Biber, D., Conrad, S., \& Leech, G. (2003). Longman Student Grammar of Spoken and Written English. Edinburgh, Harlow: Longman.

Catford, J. C. (1978). A Linguistic Theory of Translation. Oxford: Oxford University Press.

Đorđević, R. (1987). Uvod u kontrastiranje jezika. Beograd: Zavod za udžbenike i nastavna sredstva.

Eco, U. (1994). The Limits of Interpretation.Advances in Semiotics. Indiana University Press.

Eco, U. (2008). Experiences in Translation. Toronto Buffalo London: University of Toronto Press.

Hlebec, B. (2009). Prevodilačke tehnike i postupci. Novi Sad: Budućnost.

Ivir, V. (1978). Teorija i tehnika prevođenja. Udžbenik za I i II god. pozivnousmerenog obrazovanja $i$ vaspitanja srednjeg stupnja prevodilačke struke. Sremski Karlovci: Centar "Karlovačka gimnazija".

Newmark, P. (1988). A Textbook of Translation. Prentice Hall: Longman ELT.

Nida, E.A., \& Taber, C.T. (1982). The Theory and Practice of Translation. $2^{\text {nd }}$ reprint. Leiden: E. J. Brill.

Prćić, T. (2008). Semantika i pragmatika reči. Drugo, dopunjeno izdanje. Novi Sad: Zmaj.

Stojnić, M. (1980). O prevođenju književnog teksta. Sarajevo: IGKRO Svjetlost, OOUR Zavod za udžbenike. 


\section{Corpus}

McEwan, I. (2007). On Chesil Beach. Doubleday.

Makjuan, I. (2007). Čezil Bič. (A. Božović, prev.). Beograd: Paideia.

\section{O NEKIM ASPEKTIMA PREVOĐENJA: ČEZIL BIČ IJANA MAKJUANA I PREVOD DELA NA SRPSKI}

Rezime: Cilj rada je analiza pojedinih segmenata romana On Chesil Beach autora Ijana Makjuana i njihov prevod na srpski jezik. Glavni cilj jeste da ispita u kojoj meri je prevodilac uspeo da sačuva značenjske nijanse iz originalnog teksta u srpskom jeziku, kao i u kojoj meri se prevedeni tekst razlikuje od originala. Kako bi se ostvario cilj, prevod se analizira na semantičkom i pragmatičkom nivou. Semantička analiza treba da pokaže koje leksičke jedinice se koriste kako bi se uspešno prenela izvorna poruka. Sa druge strane, analiza na pragmatičkom nivou, koja obuhvata i lingvističke i vanlingvističke elemente, u središtu ispitivanja treba da ima kulturološki specifične elemente izvornog teksta koji se prenose na srpski jezik. U radu se koristi metoda kontrastivne analize, kako bi se jezik izvornog teksta uporedio u pogledu sličnosti i razlika sa jezikom teksta na srpskom jeziku. Dobijeni rezultati pokazuju da je poruka originalnog teksta, pisanog na engleskom jeziku, u većini slučajeva uspešno prenesena na srpski jezik.

Ključne reči: prevođenje, kontrastivna analiza, semantički nivo, pragmatički nivo 